TITLE:

\title{
Syntheses and structures of terminal arylalumylene complexes.
}

$\operatorname{AUTHOR}(\mathrm{S})$ :

Nagata, Koichi; Agou, Tomohiro; Tokitoh, Norihiro

\section{CITATION:}

Nagata, Koichi ...[et al]. Syntheses and structures of terminal

arylalumylene complexes.. Angewandte Chemie 2014, 53(15): 3881-3884

\section{ISSUE DATE:}

2014-04-07

URL:

http://hdl.handle.net/2433/199593

\section{RIGHT:}

This is the peer reviewed version of the following article: Nagata, K., Agou, T. and Tokitoh, N. (2014), Syntheses and Structures of Terminal Arylalumylene Complexes. Angew. Chem. Int. Ed., 53: 3881-3884, which has been published in final form at http://dx.doi.org/10.1002/anie.201310559. This article may be used for non-commercial purposes in accordance with Wiley Terms and Conditions for Self-Archiving.; This is not the published version. Please cite only the published version.; この論文は出版社版でありません。引用の際には出版社版をご確認ご利用ください。 


\title{
Syntheses and Structures of Terminal Arylalumylene Complexes
}

\author{
Koichi Nagata, Tomohiro Agou, and Norihiro Tokitoh*
}

Dedicated to Prof. Renji Okazaki on the occasion of his 77th birthday.

\begin{abstract}
Terminal arylalumylene complexes of platinum [Ar-Al$\left.\mathrm{Pt}\left(\mathrm{PCy}_{3}\right)_{2}\right] \quad\left(\mathrm{Ar}=\mathrm{Bbp} \quad\right.$ or $\quad \mathrm{Tbb}, \quad \mathrm{Bbp}=2,6-\left[\mathrm{CH}\left(\mathrm{SiMe}_{3}\right)_{2}\right]_{2} \mathrm{C}_{6} \mathrm{H}_{3}$, $\left.\mathrm{Tb} b=2,6-\left[\mathrm{CH}\left(\mathrm{SiMe}_{3}\right)_{2}\right]_{2}-4-(\mathrm{t}-\mathrm{Bu}) \mathrm{C}_{6} \mathrm{H}_{2}\right)$ have been synthesized by the reaction of a dialumene-benzene adduct with $\left[\mathrm{Pt}\left(\mathrm{PCy}_{3}\right)_{2}\right]$ or by the reduction of 1,2-dibromodialumanes $\mathrm{Ar}(\mathrm{Br}) \mathrm{Al}-\mathrm{Al}(\mathrm{Br}) \mathrm{Ar}$ in the presence of $\left[\mathrm{Pt}\left(\mathrm{PCy}_{3}\right)_{2}\right] . X$-Ray crystallographic analysis revealed that the Al-Pt bond lengths of these arylalumylene complexes are shorter than the previously reported shortest Al-Pt distance. DFT calculations suggested that the Al-Pt bonds in the arylalumylene complexes have significantly high electrostatic character rather than covalent character.
\end{abstract}

Transition metal complexes of subvalent main group element compounds attract considerable attention, because of not only their unique electronic structures but also their synthetic potentials in organometallic chemistry. Especially, complexes of group 13 metallylenes (:ER, E = B, Al, Ga, In, and $\mathrm{Tl}$ ) are expected to show particular bonding interactions between the subvalent group 13 elements and transition metal fragments, since these metallylenes posses a lone pair and two vacant p orbitals and may act as $\sigma$ donor/ $\pi$-acceptor ligands. ${ }^{[1]}$ Recently, the chemistry of borylene complexes has been extensively developed, ${ }^{[2]}$ while the examples of heavier group 13 metallylene complexes with the formula of [M(ER $\left.)_{\mathrm{mLn}}\right]$ (R: anionic monodentate ligands) have been limited for the gallium and indium homologues and are yet to be reported for aluminum. ${ }^{[3]}$ Although Lewis base-coordinated terminal alumylene complexes (e.g., complexes I, II, and III in Figure 1) have been synthesized as stable compounds, ${ }^{[4-7]}$ there has been no alumylene complexes featuring two-coordinated subvalent aluminum moieties (i.e, complex IV). Because the coordination of Lewis bases may

[*] K. Nagata, Dr. T. Agou, Prof. Dr. N. Tokitoh Institute for Chemical Research, Kyoto University Gokasho, Uji, Kyoto 611-0011 (Japan) Fax: (+81) 774-38-3203

E-mail: tokitoh@boc.kuicr.kyoto-u.ac.jp

[**] This work was supported by JSPS KAKENHI (Nos. 22350017, 24550048, 24655028, and 24109013), by Grants for Excellent Graduate Schools, MEXT, Japan, and by the "Molecular Systems Research" project of RIKEN Advanced Science Institute. T.A. thanks to the Kyoto Technoscience Center and the Research Institute for Production Development for the financial supports. K.N. acknowledges the support by a Grants-in-Aid for JSPS Fellows from JSPS (No. 252926). The synchrotron radiation experiments were performed at the BL38B1 beamline of the SPring-8 with the approval of the Japan Synchrotron Radiation Research Institute (JASRI; proposal No. 2013A1183). The authors are grateful to Dr. K. Miura, Dr. S. Baba, and Dr. N. Mizuno (JASRI) for the X-ray crystallographic analyses at the SPring-8.

Supporting information for this article is available on the WWW under http://www.angewandte.org or from the author. mask the intrinsic nature of the alumylene ligands, it has been desired to develop Lewis base-free alumylene complexes in order to elucidate the bonding situation between the alumylene and transition metal moieties. Herein, we report the syntheses and structures of platinum complexes of arylalumylenes, which are the first examples of Lewis base-free alumylene complexes.

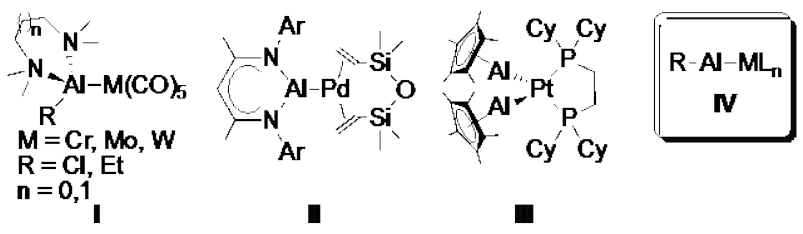

Figure 1. Transition metal complexes of Lewis base-coordinated (I-III) and Lewis base-free (IV) alumylenes. $\mathrm{Ar}=2,6-(i-\mathrm{Pr})_{2} \mathrm{C}_{6} \mathrm{H}_{3}$

Recently, we have communicated a reactivity of dialumenebenzene adduct 2 as a synthetic equivalent of diaryldialumene $\mathrm{BbpAl}=\mathrm{AlBbp} .{ }^{[8,9]}$ During the research on the reactivities of $\mathbf{2}$, the reaction of 2 and $\left[\mathrm{Pt}\left(\mathrm{PCy}_{3}\right)_{2}\right]$ was investigated with the expectation of trapping of the dialumene as a $\pi$-dialumene complex of platinum. ${ }^{[10]}$ The reaction progress was monitored by ${ }^{31} \mathrm{P}$ NMR spectroscopy, showing the formation of a mixture containing a new platinum complex $\left(\delta_{\square}=69.9 \mathrm{ppm}\right)$. Fractional crystallization of the crude material from $n$-hexane at $-35{ }^{\circ} \mathrm{C}$ yielded a small amount (3\%) of arylalumylene complex 1a as air- and moisture-sensitive dark red crystals (Scheme 1). The formation of 1a implies that compound $\mathbf{2}$ has reactivities as an arylalumylene source in addition to the diaryldialumene synthon. After screening of the reaction conditions, finally, reduction of 1,2-dibromodialumanes $\mathbf{3 a}^{[11]}$ and $3 \mathbf{b}$ with $\mathrm{KC}_{8}$ in the presence of $\left[\mathrm{Pt}\left(\mathrm{PC}_{3}\right)_{2}\right]$ was found to afford $\mathbf{1 a}$ and $\mathbf{1 b}$, respectively, as sole products. After recrystallization from $n$-hexane at $-35{ }^{\circ} \mathrm{C}$, the arylalumylene complexes were obtained in moderate yields (1a: $72 \%$, 1b: 21\%). Complexes $\mathbf{1 a}$ and $\mathbf{1 b}$ are stable up to 79 and $110{ }^{\circ} \mathrm{C}$ in the solid state, respectively, though they slowly decompose in solution even at $-35{ }^{\circ} \mathrm{C}$ to give complicated mixtures containing $\left[\mathrm{Pt}\left(\mathrm{PCy}_{3}\right)_{2}\right]$ and $\mathrm{PC} y_{3}$.

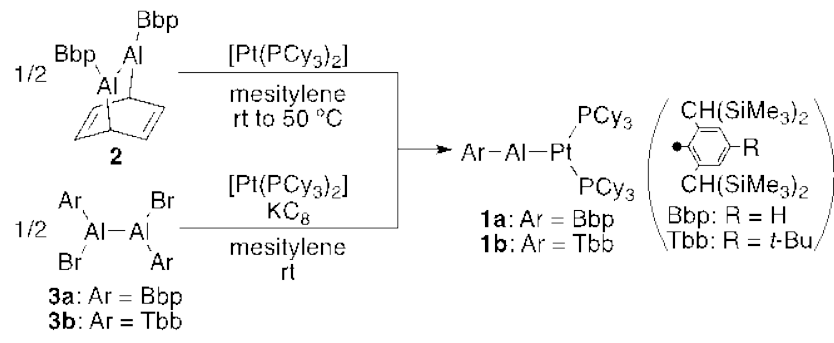

Scheme 1. Syntheses of arylalumylene complexes $\mathbf{1 a}$ and $\mathbf{1 b}$ 
In the ${ }^{31} \mathrm{P}$ NMR spectra, complexes $\mathbf{1 a}$ and $\mathbf{1 b}$ exhibit singlet signals accompanied by ${ }^{195} \mathrm{Pt}$ satellites at $\delta=69.9 \mathrm{ppm}\left({ }^{1}{ }_{\mathrm{PPt}}=4015\right.$ $\mathrm{Hz})$ and at $\delta=69.8 \mathrm{ppm}\left({ }^{1} \mathrm{JPt}_{\mathrm{PP}}=4033 \mathrm{~Hz}\right)$, respectively, which are downfield shifted with respect to those of $\left[\mathrm{Pt}\left(\mathrm{PCy}_{3}\right)_{2}\right](\delta=62.3 \mathrm{ppm}$, ${ }^{1} J_{\mathrm{PPt}}=4160 \mathrm{~Hz}$ ) and the structurally related carbonyl complex $\left[\left(\mathrm{Cy}_{3} \mathrm{P}\right)_{2} \mathrm{Pt}(\mathrm{CO})\right]\left(\delta=63.7 \mathrm{ppm},{ }^{1} \mathrm{JPP}_{\mathrm{Pt}}=4101 \mathrm{~Hz}\right) .{ }^{[12]}$ Definite signals could not be observed in the ${ }^{27} \mathrm{Al}$ and ${ }^{195} \mathrm{Pt}$ NMR spectra of complexes 1a and $\mathbf{1 b}$, probably because of the signal broadening caused by the high quadrupole moment of the ${ }^{27} \mathrm{Al}$ nuclei.

Molecular structures of complexes 1a and $\mathbf{1 b}$ were determined by X-ray crystallographic analyses, showing that the aluminum atoms are definitely two-coordinated and are bound to the platinum atoms in terminal fashions with the C1-Al1-Pt1 angles of 179.2(2) (1a) and 173.96(14) ${ }^{\circ}$ (1b) (Figure 2). The platinum centers adopt distorted trigonal planar geometries. The Pt1-Al1 bonds of the arylalumylene complexes (1a: 2.2857(18) $\AA$, 1b: 2.2829(13) $\AA$ ) are slightly shortened compared with the shortest Pt-Al distance previously reported (2.327(2) $\AA$ ), ${ }^{[6 e]}$ most likely due to the decreased coordination number of platinum as well as the difference in the aluminum-bound substituents. ${ }^{[13]}$
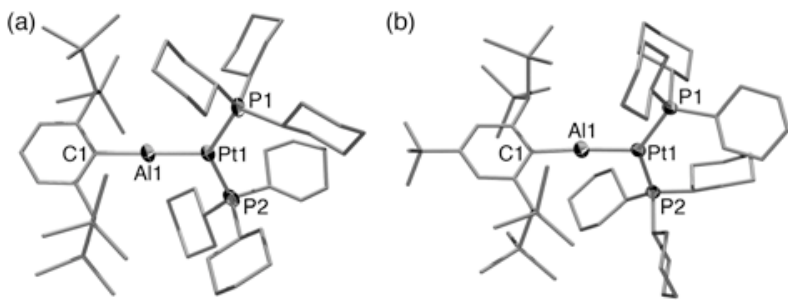

Figure 2. Molecular structures of (a) $\mathbf{1 a}$ and (b) $\mathbf{1 b}$. Thermal ellipsoids are drawn at the $50 \%$ probability level. Hydrogen atoms are omitted, and $\mathrm{Bbp}, \mathrm{Tbb}$, and $\mathrm{Cy}$ group are shown in wireframe format for clarity. Three Cy and two Me groups in complex 1a were disordered over two positions (see the Supporting Information for detail). Selected bond lengths $[\AA]$ and angles [०]: (for 1a) Al1-Pt1 2.2857(18), C1-Al1 2.001(6), Pt1-P1 2.2828(17), Pt1-P2 2.2903(16), C1-Al1-Pt1 179.2(2), Al1-Pt1-P1 114.86(6), Al1-Pt1-P2 117.85(6), P1-Pt1-P2 127.29(6); (for 1b) Al1-Pt1 2.2829(13), C1-Al1 1.986(4), Pt1-P1 2.3071(9), Pt1-P2 2.2673(10), C1-Al1-Pt1 173.96(14), Al1-Pt1-P1 119.14(4), Al1-Pt1-P2 109.20(4), P1-Pt1-P2 131.56(4).

To gain further information on the bonding situation in 1a and 1b, density functional theory (DFT) calculations at the M062X ${ }^{[14]} /$ SDD[Pt]:6-311G(2df)[Al,P]:6-31G(d)[Si,C,H] level were performed on a real molecule of 1a. The comparison of the optimized and experimental bond lengths and angles of 1a shows that the DFT-optimized structure well reproduces that found in the single crystals. The natural bond orbital (NBO) analysis ${ }^{[15]}$ on the optimized geometry of 1a showed that the Al-Pt bond has a small Wiberg bond index (0.59), indicating that the Al-Pt bond is highly ionic and that the contribution of the covalent interaction is less important. ${ }^{[6 e, 16]}$ The calculated NBO corresponding to the Al-Pt bond is predominantly formed from the overlap of the $3 \mathrm{~s}(\mathrm{Al})$ and $6 \mathrm{~s}(\mathrm{Pt})$ orbitals $\left(\sigma(\mathrm{Al}-\mathrm{Pt})=0.87\left(3 \mathrm{~s} 3 \mathrm{p}^{0.03}\right) \mathrm{Al}+0.50\left(6 \mathrm{~s} 6 \mathrm{p}^{0.03} 6 \mathrm{~d}^{0.02}\right) \mathrm{Pt}\right)$. Meanwhile, the $\mathrm{Pt} \rightarrow \mathrm{Al} \pi$-back donation interactions were identified as donor/acceptor interactions, and the stabilization energies by the two $5 \mathrm{~d}(\mathrm{Pt}) \rightarrow 3 \mathrm{p}(\mathrm{Al}) \pi$-back donations were estimated to be 19.86 and $4.54 \mathrm{kcal} \mathrm{mol}^{-1}$ by the second-order perturbation theory analysis The nature of the Al-Pt bond in 1a was further investigated in terms of the energy decomposition analysis, ${ }^{[17,18]}$ showing that the $\mathrm{Al}-\mathrm{Pt}$ bonding interaction is mainly electrostatic. The electrostatic interaction contributes $74.0 \%$ of the total attractive interactions between the $\mathrm{BbpAl}$ and $\left[\mathrm{Pt}\left(\mathrm{PCy}_{3}\right)_{2}\right]$ moieties. The breakdown of the $\mathrm{Al}-\mathrm{Pt}$ orbital interaction energy into $\sigma$ - and $\pi$-components indicates that the $\mathrm{Al} \quad \pi=\mathbb{B}$ Atck $\square$ lonation significantly contributes to the covalent bonding ( $\sigma: 55.8 \%, \pi: 44.2 \%)$.

In summary, the first Lewis base-free terminal arylalumylene complexes were obtained by two different routes: the treatment of the dialumene-benzene adduct with $\left[\mathrm{Pt}\left(\mathrm{PCy}_{3}\right)_{2}\right]$ and the reduction of the 1,2-dibromodialumanes in the presence of $\left[\mathrm{Pt}\left(\mathrm{PCy}_{3}\right)_{2}\right]$. The $\mathrm{Al}-$ Pt bonds in the arylalumylene complexes were shortened compared to the previously reported $\mathrm{Al}-\mathrm{Pt}$ distances, indicating the stronger bonding interactions between the alumylene and platinum moieties. The DFT calculations suggested that the Al-Pt bonds in the arylalumylene complexes possess significantly high electrostatic character and that the contribution of the $\mathrm{Pt} \rightarrow \mathrm{Al} \pi$-back donation to the covalent interactions is comparable to that of the $\mathrm{Al} \quad \sigma \rightarrow \mathrm{Pt}$ donation.

\section{Experimental Section}

All the manipulations were performed under a dry argon atmosphere by using the Schlenk techniques and glove boxes. Solvents were purified by the Ultimate Solvent System, Glass Contour Company ${ }^{[19]}$ (n-hexane) or by the bulb-to-bulb distillation from a potassium mirror $\left(\mathrm{C}_{6} \mathrm{D}_{6}\right.$ and mesitylene). $\left[\mathrm{Pt}\left(\mathrm{PCy}_{3}\right)_{2}\right]$ was prepared according to a literature. ${ }^{[20]}$

Reaction of 2 with [Pt( $\left.\left(\mathrm{PCy}_{3}\right)_{2}\right]$ : A solution of $2(13.4 \mathrm{mg}, 0.0124 \mathrm{mmol})$ and $\left[\mathrm{Pt}\left(\mathrm{PCy}_{3}\right)_{2}\right](17.4 \mathrm{mg}, 0.0230 \mathrm{mmol})$ in mesitylene $(2 \mathrm{~mL})$ was stirred at room temperature for $2.5 \mathrm{~h}$ and then at $50{ }^{\circ} \mathrm{C}$ for $2 \mathrm{~h}$, affording a mixture containing 1a and $\left[\mathrm{Pt}\left(\mathrm{PCy}_{3}\right)_{2}\right]$ in a ratio of $\mathrm{ca}$. 1.0:1.5. Small amount of pure 1 a (1.0 mg, $0.00085 \mathrm{mmol}$, 3\%) was obtained by fractional crystallization from $n$-hexane at $-35^{\circ} \mathrm{C}$.

Reduction of $\mathbf{3 a}$ in the presence of $\left[\mathrm{Pt}\left(\mathrm{PCy}_{3}\right)_{2}\right]$ : To a mesitylene $(5 \mathrm{~mL})$ solution of $3 \mathbf{a}(13.2 \mathrm{mg}, 0.013 \mathrm{mmol})$ and $\left[\mathrm{Pt}\left(\mathrm{PCy}_{3}\right)_{2}\right](19.0 \mathrm{mg}, 0.025$ mmol) was added $\mathrm{KC}_{8}(3.8 \mathrm{mg}, 0.028 \mathrm{mmol})$. The mixture was stirred at room temperature for $4.5 \mathrm{~h}$. After removal of the solvents, the residue was extracted with $n$-hexane and filtered. The filtrate was concentrated and stored at $-35{ }^{\circ} \mathrm{C}$ to give $1 \mathrm{a}$ as dark red crystals (22.2 $\left.\mathrm{mg}, 0.019 \mathrm{mmol}, 72 \%\right)$. m.p. $79{ }^{\circ} \mathrm{C}$ (dec.); ${ }^{1} \mathrm{H}$ NMR (600 MHz, $\left.\mathrm{C}_{6} \mathrm{D}_{6}\right): \delta=0.29$ (s, 36H, Si $\left.\left(\mathrm{CH}_{3}\right)_{3}\right), 1.22-$ 1.43 (m, 24H, Cy), 1.65-1.73 (m, 18H, Cy), 1.90-1.92 (m, 12H, Cy), 2.202.22 (m, 12H, Cy), 2.75 (s, 2H, CH(SiMe $\left.)_{2}\right), 6.78$ (d, ${ }^{3} \mathrm{~J}=7.7 \mathrm{~Hz}, 2 \mathrm{H}, m-$ $\mathrm{ArH}), 7.08\left(\mathrm{t},{ }^{3} \mathrm{~J}=7.7 \mathrm{~Hz}, 1 \mathrm{H}, p-\mathrm{ArH}\right) ;{ }^{13} \mathrm{C}\left\{{ }^{1} \mathrm{H}\right\}$ NMR $\left(151 \mathrm{MHz}, \mathrm{C}_{6} \mathrm{D}_{6}\right)$ : $\delta=1.28$ (s, SiMe $\left.e_{3}\right), 27.1$ (s, $C^{4}(\mathrm{Cy})$ ), 28.3 (virtual triplet, $J_{\mathrm{CP}}=4.5 \mathrm{~Hz}$, $C^{2,6}(\mathrm{Cy})$ ), 31.2 (s, $\left.\mathrm{CH}\left(\mathrm{SiMe}_{3}\right)_{2}\right), 31.3\left(\mathrm{~s},{ }^{4} J_{\mathrm{CPt}}=24.1 \mathrm{~Hz}, C^{3,5}(\mathrm{Cy})\right), 41.3$ (virtual triplet, $J_{\mathrm{CP}}=9.1 \mathrm{~Hz},{ }^{2} J_{\mathrm{CPt}}=36.2 \mathrm{~Hz}, C^{1}(\mathrm{Cy})$ ), $123.9\left(\mathrm{~s},{ }^{4} J_{\mathrm{CPt}}=22.7\right.$ Hz, m-C(Ar)), 129.22 (s, $p-C(\mathrm{Ar})$ ), 149.4 (s, o-C(Ar)), 160.0 (t, ${ }^{3} J_{\mathrm{CP}}=25.7$ $\mathrm{Hz}$, ipso-C(Ar)); ${ }^{31} \mathrm{P}$ NMR (120 MHz, $\left.\mathrm{C}_{6} \mathrm{D}_{6}\right): \delta=69.9\left(\mathrm{~s},{ }^{1} J_{\mathrm{PPt}}=4015 \mathrm{~Hz}\right)$; UV/vis (hexane): $\lambda=447$ ( $\varepsilon$ 1600), 488 ( $\varepsilon$ 1800) nm; UV/vis (THF): $\lambda=446$ ( $\varepsilon$ 1400), 489 ( $\varepsilon$ 1500) nm; HRMS (DART-TOF, positive mode) $\mathrm{m} / \mathrm{z}$ calcd. for $\left[\mathrm{C}_{56} \mathrm{H}_{107} \mathrm{AlP}_{2} \mathrm{Si}_{4}{ }^{195} \mathrm{Pt}\right]^{+}$: 1175.6388 ; found: 1175.6412 .

1b: As described for the reduction of 3a, a mesitylene $(5 \mathrm{~mL})$ solution of 3b (21.5 mg, $0.0193 \mathrm{mmol})$ and [Pt( $\left.\left.\mathrm{PCy}_{3}\right)_{2}\right]$ (29.1 mg, $\left.0.0386 \mathrm{mmol}\right)$ was treated with $\mathrm{KC}_{8}(5.3 \mathrm{mg}, 0.039 \mathrm{mmol})$. After workup and recrystallization, 1b was obtained as dark red crystals (10.0 mg. $0.0082 \mathrm{mmol}, 21 \%)$. m.p. 110 ${ }^{\circ} \mathrm{C}$ (dec.); ${ }^{1} \mathrm{H}$ NMR (600 MHz, $\mathrm{C}_{6} \mathrm{D}_{6}$ ): $\delta=0.32$ (s, 36H, Si $\left.\left(\mathrm{CH}_{3}\right)_{3}\right), 1.20-1.44$ (m, 24H, Cy), 1.35 (s, 9H, C( $\left.\left(\mathrm{CH}_{3}\right)_{3}\right), 1.68-1.72(\mathrm{~m}, 18 \mathrm{H}, \mathrm{Cy}), 1.90-1.92$ (m, 12H, Cy), 2.21-2.23 (m, 12H, Cy), 2.72 (s, 2H, CH(SiMe $\left.)_{2}\right), 6.81$ (s, 2H, m$\mathrm{ArH}) ;{ }^{13} \mathrm{C}\left\{{ }^{1} \mathrm{H}\right\}$ NMR (151 MHz, $\left.\mathrm{C}_{6} \mathrm{D}_{6}\right): \delta=1.30$ (s, SiMe $\left.e_{3}\right), 27.1$ (s, $C^{4}(\mathrm{Cy})$ ), 28.3 (virtual triplet, $J_{\mathrm{CP}}=4.6 \mathrm{~Hz}, C^{2,6}(\mathrm{Cy})$ ), $31.0\left(\mathrm{~s}, \mathrm{CH}\left(\mathrm{SiMe}_{3}\right)_{2}\right), 31.2$ (s, $C^{3,5}(\mathrm{Cy})$ ), 31.4 (s, $\mathrm{CMe}_{3}$ ), 34.5 (s, $\mathrm{CMe}_{3}$ ), 41.4 (virtual triplet, $J_{\mathrm{CP}}=8.3 \mathrm{~Hz}$, $\left.C^{1}(\mathrm{Cy})\right), 121.3\left(\mathrm{~s},{ }^{4} J_{\mathrm{CPt}}=22.7 \mathrm{~Hz}, m-C(\mathrm{Ar})\right), 149.0$ (s, $\left.p-C(\mathrm{Ar})\right), 151.1$ (s, o$C(\mathrm{Ar})), 157.0\left(\mathrm{t},{ }^{3} J_{\mathrm{CP}}=27.2 \mathrm{~Hz}\right.$, ipso-C(Ar)); ${ }^{31} \mathrm{P}$ NMR $\left(243 \mathrm{MHz}, \mathrm{C}_{6} \mathrm{D}_{6}\right)$ : $\delta=69.8\left(\mathrm{~s},{ }^{1} J_{\mathrm{PPt}}=4033 \mathrm{~Hz}\right) ; \mathrm{UV} / \mathrm{vis}$ (hexane): $\lambda=447$ ( $\left.\varepsilon 1700\right), 483(\varepsilon 1900)$ nm; UV/vis (THF): $\lambda=447$ ( $\varepsilon$ 1500), 483 ( $\varepsilon$ 1600) nm; HRMS (DART-TOF, positive mode) $\mathrm{m} / \mathrm{z}$ calcd. for $\left[\mathrm{C}_{60} \mathrm{H}_{115} \mathrm{AlP}_{2} \mathrm{Si}_{4}{ }^{195} \mathrm{Pt}\right]^{+}: 1231.7021$; found: 1231.7026.

Single crystals of $\mathbf{1 a}$ and $\mathbf{1} \mathbf{b} \cdot$ hexane were obtained by cooling their saturated solutions in $n$-hexane to $-35{ }^{\circ} \mathrm{C}$. The crystal data of 1 a was collected on a Rigaku Saturn 70 CCD diffractometer with a VariMax Mo Optic System using a Mo $K \alpha$ radiation $(\lambda=0.71070 \AA)$, while that of 
$\mathbf{1 b} \cdot$ hexane was collected at the BL38B1 beamline of the SPring-8 using an ADSC Quantum 315 CCD detector and Si(111)-monochromated X-ray radiation $(\lambda=0.85000 \AA)$. The structures were solved with the Shelx program package. ${ }^{[21]}$ Crystal data for 1a: monoclinic , space group $P 2{ }_{1} / \mathrm{C},-173{ }^{\circ} \mathrm{C}$, $a=13.1525(3), b=19.5941(4), c=24.5674(5) \AA, \beta=96.2678(15), V=6293.5(2)$ $\AA^{3}, \quad Z=4, \mu=2.402 \mathrm{~mm}^{-1}(\lambda=0.71070 \AA), 2.08^{\circ}<\theta<25.50^{\circ}, \quad R_{\mathrm{int}}=0.0845$, Completeness to $\theta_{\max } 99.9 \%, 760$ parameters refined, $R_{1}(I>2 \sigma(I))=0.0456$, $\mathrm{w} R_{2}$ (all data) $=0.1110, \mathrm{GOF}=1.018$, largest diff. peak and hole 1.917 and 1.714 e $\AA^{-3}$. Crystal data for $\mathbf{1 b} \cdot$ hexane: triclinic, space group $P-1,-170{ }^{\circ} \mathrm{C}$, $a=12.5246(1), b=13.9973(2), c=21.9295(3) \AA, \alpha=89.9651(6), \beta=83.0595(5)$, $\gamma=73.3812(6)^{\circ}, \quad V=3654.56(8) \AA^{3}, \quad Z=2, \mu=0.243 \mathrm{~mm}^{-1}(\lambda=0.85000 \AA)$, $2.05^{\circ}<\theta<31.00^{\circ}, R_{\mathrm{int}}=0.0507$, Completeness to $\theta_{\max } 99.0 \%, 683$ parameters refined, $R_{1}(I>2 \sigma(I))=0.0423$, w $R_{2}$ (all data) $=0.1172, \mathrm{GOF}=1.086$, largest diff. peak and hole 1.253 and -2.204 e $\AA^{-3}$. CCDC-948098 (1a) and 948113 (1b•hexane) contain the supplementary crystallographic data for this paper. These date can be obtained free of charge from The Cambridge Crystallographic Data Centre via www.ccdc.cam.ac.uk/data_request/cif.

Received: ((will be filled in by the editorial staff))

Published online on ((will be filled in by the editorial staff))

Keywords: platinum · aluminum · alumylene · alumylene complexes · density functional calculations

[1] Theoretical studies on the coordination behavior of heavier group 13 metallylenes: a) K. K. Pandey, S. Aldridge, Polyhedron 2012, 43, 131; b) K. K. Pandey, H. Braunschweig, A. Lledós, Inorg. Chem. 2011, 50, 1402; c) K. K. Pandey, S. Aldridge, Inorg. Chem. 2011, 50, 1798; d) K. K. Pandey, D. J. Musaev, Organometallics 2010, 29, 142; e) J. A. Gámez, R. Tonner, G. Frenking, Organometallics 2010, 29, 5676; f) K. K. Pandey, A. Lledós, F. Maseras, Organometallics 2009, 28, 6442; g) S. Aldridge, A. Rossin, D. L. Coombs, D. J. Willock, Dalton Trans. 2004, 2649; h) G. Frenking, K. Wichmann, N. Fröhlich, C. Loschen, M. Lein, J. Frunzke, V. M. Rayón, Coord. Chem. Rev. 2003, 238-239, 55; i) J. Udding, G. Frenking, J. Am. Chem. Soc. 2001, 123, 1683; j) G. Frenking, N. Fröhlich, Chem. Rev. 2000, 100, 717; k) C. L. B. Macdonald, A. H. Cowley, J. Am. Chem. Soc. 1999, 121, 12113; l) F. A. Cotton, X. Feng, Organometallics 1998, 17, 128.

[2] a) H. Braunschweig, R. D. Dewhurst, H. Viktoria, H. Chem. Soc. Rev 2013, 42, 3197; b) H. Braunschweig, R. D. Dewhurst, A. Schneider, Chem. Rev. 2010, 110, 3924; c) D. Vidovic, G. A. Pierce, S. Aldridge, Chem. Commun. 2009, 1157.

[3] a) T. Muraoka, H. Motohashi, Y. Kazuie, A. Takizawa, K. Ueno, Organometallics 2009, 28, 1616; b) N. D. Coombs, D. Vidovic, J. K. Day, A. L. Thompson, D. D. Le Pevelen, A. Stasch, W. Clegg, L. Russo, L. Male, M. Hursthouse, D. J. Willock, S. Aldridge, J. Am. Chem. Soc. 2008, 130, 16111; c) N. D. Coombs, W. Clegg, A. L. Thompson, D. J. Willock, S. Aldridge, J. Am. Chem. Soc. 2008, 130, 5449; d) T. Cadenbach, C. Gemel, D. Zacher, R. A. Fischer, Angew. Chem. 2008, 120, 3487; Angew. Chem. Int. Ed. 2008, 47, 3438; e) T. Muraoka, H. Motohashi, M. Hirotsu, K. Ueno, Organometallics 2008, 27, 3918; f) B. Quillian, Y. Wang, P. We, G. H. Robinson, New J. Chem. 2008, 32, 774; g) X.-J. Yang, Y. Wang, B. Quillian, P. Wei, Z. Chen, P. v. R. Schleyer, G. H. Robinson, Organometallics 2006, 25, 925; h) M. Cokoja, C. Gemel, T. Steinke, F. Schröder, R. A. Fischer, Dalton Trans. 2005, 44; i) X.-J. Yang, B. Quillian, Y. Wang, P. Wei, G. H. Robinson, Organometallics 2004, 23, 5119; j) N. R. Bunn, S. Aldridge, D. L. Coombs, A. Rossin, D. J. Willock, C. Jones, J.-L. Ooi, Chem. Commun. 2004, 1732; k) K. Ueno, T. Watanabe, H. Tobita, H. Ogino, Organometallics 2003, 22, 4375; l) N. J. Hardman, R. J. Wright, A. D. Phillips, P. P. Power, J. Am. Chem. Soc. 2003, 125, 2667; m) W. Uhl, M. Benter, S. Melle, W. Saak, G. Frenking, J. Uddin, Organometallics 1999, 18, 3778; n) S. T. Haubrich, P. P. Power, J. Am. Chem. Soc. 1998, 120, 2202; o) J. R. Su, X.-W. Li, R. C.
Crittendon, C. F. Campana, G. H. Robinson, Organometallics 1997, 16, 4511.

[4] a) R. A. Fischer, M. M. Schulte, J. Weiss, L. Zsolnai, A. Jacobi, G. Huttner, G. Frenking, C. Boehme, S. Vyboishchikov, J. Am. Chem. Soc. 1998, 120, 1237; b) M. M. Schulte, E. Herdtweck, G. RaudaschlSieber, R. A. Fischer, Angew. Chem. 1996, 108, 489; Angew. Chem., Int. Ed. Engl. 1996, 35, 424.

[5] a) A. Kempter, C. Gemel, R. A. Fischer, Chem. Eur. J. 2007, 13, 2990; b) A. Kempter, C. Gemel, R. A. Fischer, Chem. Commun. 2006, 1551.

[6] a) B. Buchin, T. Steinke, C. Gemel, T. Cadenbach, R. A. Fischer, Z. Anorg. Allg. Chem. 2005, 63, 2756; b) T. Steinke, C. Gemel, M. Winter, R. A. Fischer, Chem. Eur. J. 2005, 11, 1636; c) T. Steinke, M. Cokoja, C. Gemel, A. Kempter, A. Krapp, G. Frenking, U. Zenneck, R. A. Fischer, Angew. Chem. 2005, 117, 3003; Angew. Chem. Int. Ed. 2005, 44, 2943; d) T. Steinke, C. Gemel, M. Winter, R. A. Fischer, Chem. Eur. J. 2005, 11, 1636; e) D. Weiss, T. Steinke, M. Winter, R. A. Fischer, N. Fröhlich, J. Uddin, G. Frenking, Organometallics 2000, 19, 4583; f) Q. Yu, A. Purath, A. Donchev, H. Schnöckel, J. Organomet. Chem. 1999, 584, 94; g) J. Weiss, D. Stetzkamp, B. Nuber, R. A. Fischer, C. Boehme, G. Frenking, Angew. Chem. 1997, 109, 95; Angew. Chem., Int. Ed. Engl. 1997, 36, 70.

[7] Dinuclear complexes bearing bridging alkylalumylene ligands: a) J. T. Golden, T. H. Peterson, P. L. Holland, R. G. Bergman, R. A. Andersen, J. Am. Chem. Soc. 1998, 120, 223; b) J. J. Schneider, C. Krüger, M. Nolte, I. Abraham, T. S. Ertel, H. Bertagnolli, Angew. Chem. 1994, 106, 2537; Angew. Chem., Int. Ed. Engl. 1994, 33, 2435.

[8] Generation and trapping of a 1,2-diaryldialumene: a) R. J. Wright, A. D. Phillips, P. P. Power, J. Am. Chem. Soc. 2003, 125, 10784; b) C. Cui, X. Li, C. Wang, J. Zhang, J. Cheng, X. Zhu, Angew. Chem. 2006, 118, 2303; Angew. Chem. Int. Ed. 2006, 45, 2245.

[9] Reactivities of $\mathbf{2}$ as a diaryldialumene synthon: T. Agou, K. Nagata, N. Tokitoh, Angew. Chem. 2013, 125, 11018; Angew. Chem. Int. Ed. 2013, 52, 10818.

[10] Platinum complexes of diaryldiborenes: H. Braunschweig, A. Damme, R. D. Dewhurst, A. Vargas, Nat. Chem. 2013, 5, 115.

[11] T. Agou, K. Nagata, H. Sakai, Y. Furukawa, N. Tokitoh, Organometallics 2012, 31, 3806.

[12] S. Bertsch, H. Braunschweig, M. Forster, K. Gruss, K. Radacki, Inorg Chem. 2011, 50, 1816.

[13] The optimized structure of a model complex [( $\left.\left.\eta^{5}-\mathrm{Cp} *\right) \mathrm{Al}-\mathrm{Pt}\left(\mathrm{PCy}_{3}\right)_{2}\right]$ at the M062X/SDD[Pt]:6-311G(2df)[Al,P]:6-31G(d)[C,H] level showed a slightly longer Al-Pt distance (2.309 $\AA$ ) compared to those of $\mathbf{1 a}$ and $\mathbf{1 b}$.

[14] Y. Zhao, D. G. Truhlar, Theor. Chem. Acc. 2008, 120, 215.

[15] E. D. Glendening, J. K. Badenhoop, A. E. Reed, J. E. Carpenter, J. A. Bohmann, C. M. Morales, F. Weinhold, NBO 5.0, Theoretical Chemistry Institute, University of Wisconsin, Madison, WI; 2001.

[16] J. Uddin, C. Boehme, G. Frenking, Organometallics 2000, 19, 571.

[17] a) F. M. Bickelhaupt, E. J. Baerends, in Reviews in Computational Chemistry, Vol. 15 (Eds.: K. B. Lipkowitz, D. B. Boyd), Wiley-VCH, New York, 2000, p. 1; b) T. Ziegler, A. Rauk, Inorg. Chem. 1979, 18, 1755; c) T. Ziegler, A. Rauk, Inorg. Chem. 1979, 18, 1558; d) K. Kitaura, K. Morokuma, Int. J. Quantum. Chem. 1976, 10, 325; e) K. Morokuma, J. Chem. Phys. 1971, 55, 1236.

[18] The EDA calculations were performed by using the ADF program package. a) G. te Velde, F. M. Bickelhaupt, S. J. A. van Gisbergen, C. Fonseca Guerra, E. J. Baerends, J. G. Snijders, T. Ziegler, J. Comput. Chem. 2001, 22, 931; b) C. Fonseca Guerra, J. G. Snijders, G. te Velde, E. J. Baerends, Theor. Chem. Acc. 1998, 99, 391; c) ADF 2013, SCM, Theoretical Chemistry, Urije Universiteit, Amsterdam, The Netherlands. Complete citation for the ADF program is included in the supporting information.

[19] A. B. Pangborn, M. A. Giardello, R. H. Grubbs, R. K. Rosen, F. J. Timmers, Organometallics 2004, 15, 1518.

[20] S. Otsuka, T. Yoshida, M. Matsumoto, K. Nakatsu, J. Am. Chem. Soc. 1976, 98, 5850

[21] G. M. Sheldrick, Acta Crystallogr. Sect. A 2008, A64, 112. 
Entry for the Table of Contents

Aluminum Complexes

Koichi Nagata, Dr. Tomohiro Agou, and

Prof. Dr. Norihiro Tokitoh

Page - Page

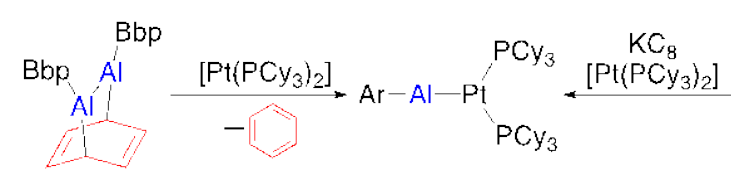

$\mathrm{Ar} \quad \mathrm{Ar}$
$(\mathrm{Ar}=\mathrm{Bbp}, \mathrm{Brb})$

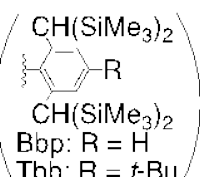

Syntheses and Structures of Terminal Arylalumylene Complexes

A terminal arylalumylene complex of platinum was obtained by the reaction of a dialumene-benzene adduct and $\left[\mathrm{Pt}\left(\mathrm{PC}_{3}\right)_{2}\right]$. Reduction of 1,2-dibromodialumanes in the presence of $\left[\mathrm{Pt}\left(\mathrm{PCy}_{3}\right)_{2}\right]$ also afforded the terminal arylalumylene complexes. DFT calculations suggested that the Al-Pt bonds in the arylalumylene complexes have significantly high electrostatic character rather than covalent character. 